\title{
Iprodione and Chlorpyrifos, Alone and in a Mixture, Impaired Male Fertility and Sexual Behavior in Adult Rats via Suppression of Steroidogenic Genes and SIRT1/TERT/PGC-1a Pathway
}

Yasmina M. Abd-Elhakim

Zagazig University Faculty of Veterinary Medicine

Nabela I. El Sharkawy

Zagazig University Faculty of Veterinary Medicine

Khlood M. El Bohy

Zagazig University Faculty of Veterinary Medicine

Mona A. Hassan ( $\triangle$ monaabdelhady91@yahoo.com )

Zagazig University Faculty of Veterinary Medicine https://orcid.org/0000-0002-8713-2553

Heba S.A. Gharib

Zagazig University Faculty of Veterinary Medicine

Abeer E. El-Metwally

Animal reproduction research institute

Ahmed Hamed Arisha

Zagazig University Faculty of Veterinary Medicine

Tamer S. Imam

Zagazig University Faculty of Veterinary Medicine

\section{Research Article}

Keywords: Iprodione, Chlorpyrifos, Male reproductive toxicity, Sexual behavior, Steroidogenic genes,

SIRT1/TERT/PGC-1a pathway.

Posted Date: March 10th, 2021

DOl: https://doi.org/10.21203/rs.3.rs-255267/v1

License: (1) This work is licensed under a Creative Commons Attribution 4.0 International License.

Read Full License 


\section{Abstract}

There is cumulative evidence that the iprodione (IPR) fungicide and the chlorpyrifos (CPF) insecticide are endocrine disruptors that can evoke reproductive toxicity. Yet, the underlying mechanisms are still unclear. Besides, the outcomes of their co-exposure to male sexual behavior and male fertility are still unknown. The effects of IPR (200 mg/kg b.wt) and CPF ( $7.45 \mathrm{mg} / \mathrm{kg}$ b.wt) single or mutual exposure for 65 days on sexual behavior, sex hormones, testicular enzymes, testis, and accessory sex gland histomorphometric measurements, apoptosis, and oxidative stress biomarkers were investigated. In addition, expression of nuclear receptor subfamily group A (NR5A1), 17ß-hydroxysteroid dehydrogenase (HSD17B3), silent information regulator type-1 (SIRT1), telomerase reverse transcriptase (TERT) and peroxisome proliferator-activated receptor gamma coactivator 1-alpha (PGC-1a) genes have been assessed. Our results revealed that the individual or concurrent IPR and CPF exposure significantly disturb the sexual behavior, semen characteristics, testicular enzymes, and male hormones level. Oxidative stress caused by IPR and CPF activates apoptosis by inducing Caspase 3 and reducing $\mathrm{Bcl}-2$. Downregulation of HSD17B3, NR5A1, and SIRT1/TERT/PGC-1 a pathway was evident. Of note, most of these disturbances were exaggerated in rats co-exposed to IPR and CPF compared to IPR or CPF alone. Conclusively, our findings verified that IPR and CPF possibly damage the male reproductive system and concurrent exposure should be avoided.

\section{Introduction}

Every year, almost 3 billion $\mathrm{kg}$ of pesticides, with a budget of about 40 billion USD, is used globally (Sharma et al. 2020). Consequently, many pesticides known as endocrine disruptors are continuously and simultaneously introduced to human and animals, which affect fertility and sexual differentiation (Ma et al. 2019). People are most frequently exposed to a mixture of pesticides by air, water, food and contaminated milk (Mehrpour et al. 2014, Rizzati et al. 2016). Likewise, insecticides are frequently mixed with fungicides in practice for simultaneous use in agricultural fields (Visalakshmi et al. 2016).

Organophosphorous insecticides are among the most worldwide-used agrochemicals (Kumar et al. 2018). In recent decades, Chlorpyrifos (CPF) is one of the most extensively used insecticides in both agricultural and domestic fields worldwide (Perez-Fernandez et al. 2020).. Exposure to CPF induced several harmful impacts like endocrine disruption (Watts 2012), hepatotoxicity (Xu et al. 2017), neurotoxicity (Burke et al. 2017), nephrotoxicity (Xu et al. 2018), and developmental toxicity (Laporte et al. 2018). Also, CPF has been reported to impair male reproduction (Li et al. 2019). The potential underlying mechanisms of CPF induced reprotoxic effects remain unclear (Zhang et al. 2020).

Fungicides are considered a critical component in fruits and vegetable production (Li et al. 2009). Iprodione (IPR) is one of the dicarboxamide fungicides, widely used for fungal control in many crops (Grabke et al. 2014). The available data about IPR toxicity are limited and do not determine risk assessments (Chaufan et al. 2019). IPR showed anti-androgenic activity by reducing testosterone levels and delay in pubertal development in the male rat (Blystone et al. 2007). Also, IPR modifies estrogens and 
androgens synthesis (Pisani et al. 2016). Nevertheless, studies so far have yet to recognize the underlying mechanisms of IPR induced reprotoxic effects.

In Egypt, IPR is widely used to control fungal diseases. Various studies have been performed on IPR residues in some fruits and vegetables, such as strawberries, apples, onions, peas, green beans, and chilli peppers (Bletsou, Hanafi, Dasenaki, \& Thomaidis, 2013; Dogheim, Gad Alla, \& El-Marsafy, 2001; Mansour, 2004). Low doses of residues will disrupt human hormonal functions as a consequence of the endocrine disrupting effect of IPR (Loutfy, Malhat, Kamel, \& Saber, 2015). In the Egyptian farms, CPF is one of the most common insecticides used by Ministry of Agriculture workers in cotton fields (Callahan et al., 2017). CPF is frequently detected in vegetables, cereals, and fruits (Angioni et al. 2011, Li et al. 2015). IPR and CPF have recently been detected by screening pesticide residues in cucumber crops in Egypt (Ahmed et al. 2019).

Various environmental pollutants have been reported to affect steroidogenic gene activities (Zimmer et al. 2011). Nuclear receptor subfamily group $A$ (NR5A1) is a primary steroidogenic gene which plays a dominant role in the gonads development (Röpke et al. 2013). Also, 17ß-hydroxysteroid dehydrogenase (HSD17B3) gene is a crucial regulator of steroidogenesis responsible for reducing active steroid hormones (Jana et al. 2006).

Numerous reports verified that exposure to CPF and IPR increment reactive oxygen species (ROS) production and apoptosis (Chaufan et al. 2019, Hussein et al. 2018, Radice et al. 1998). Several transcriptional co-activators regulate cellular apoptosis. For instance, silent information regulator type-1 (SIRT1) is related to the regulation of cell survival and apoptosis by deacetylating histones and nonhistones proteins (Wang et al. 2016). Moreover, Coussens et al. (2008) demonstrated that the SIRT1 gene deletion evidently weakened spermatogenesis, verifying the SIRT1 protein vital role in germ cell survival and spermatogenesis. In this context, SIRT1 has been involved in the regulation of telomerase reverse transcriptase (TERT) (Lin \&Elledge 2003). Also, impaired TERT expression has been implicated in spermatogenic failure (Weikert et al. 2006). The peroxisome proliferator-activated receptor gamma coactivator 1-alpha (PGC-1a) plays a main role in the regulation of mitochondrial biogenesis and function. Inactivated PGC-1a is converted by SIRT1 to the active form. TERT, indeed a vital component of telomerases, can also regulate PGC-1a (Sahin et al. 2011).

Therefore, this study investigates two main issues. First, assess the outcome of the single or co-exposure of IPR and CPF on sexual behavior, sexual hormones, testicular enzymes, testis, accessory gland architecture, oxidative stress, and apoptosis biomarkers. Second, determine whether the IPR and/or CPF induced reprotoxic effect could be related to the modulation of NR5A1, HSD17B3 and SIRT1/TERT/ PGC1a pathway in the testicular tissue.

\section{Materials And Methods \\ 2.1. Tested compounds}


IPR was obtained in a commercial form containing 50\% SC (suspension concentrate) (Ippon contains $50 \%$ IPR and $50 \%$ other ingredients) from Arysta Life Science- Egypt Ltd (Cairo, Egypt). CPF was obtained in a commercial form containing 48\% EC (emulsion concentration) (Pestban includes 48\% CPF, 20\% surface-active substances, and $32 \%$ solvent) from National Company for Agrochemicals and InvestmentAGROCHEM (Alexandria, Egypt). Using corn oil, stock IPR and CPF solution were prepared. All other chemicals were obtained from Sigma Aldrich Co. (St. Louis, MO, USA).

\subsection{Animals and experimental design}

Forty adult male Sprague Dawley rats (12-16 weeks of age; $180-240 \mathrm{~g}$ average initial weight) were obtained from the Animal House of the Faculty of Veterinary Medicine, Zagazig University, Egypt. Rats were kept with free access to a standard pellet animal diet and water ad libitum. Rats were divided into four groups of ten rats each. Control group: orally administered corn oil ( $1 \mathrm{ml} / \mathrm{rat})$. IPR group: orally received $200 \mathrm{mg} / \mathrm{kg}$ b.wt (1/20 LD ${ }_{50}$ ) (Blystone et al. 2007). CPF group: orally received $7.45 \mathrm{mg} / \mathrm{kg} \mathrm{b.wt}$ $\left(1 / 20\right.$ LD $\left._{50}\right)$ (Morgan \&El-Aty 2008) and co-exposure group: orally received $200 \mathrm{mg} / \mathrm{kg} \mathrm{b}$. wt. IPR and 7.45 $\mathrm{mg} / \mathrm{kg}$ b. wt. CPF. All treatments were given orally using gastric gavage for 65 successive days. All rats were weighed every week, the weight is recorded, and the dose volumes were determined accordingly. Throughout the experiment, the rats were closely monitored for discomfort, pain, mucosal membrane color, morbidity, and mortality.

\subsection{Assessment of sexual behavior}

Male rats were tested three times for male sexual activity to define those showing ejaculation at least two times. Behavioral tests were carried out in faint red lights. Male sexual behavior was evaluated by keeping the male in a Plexiglas arena five minutes before presenting a receptive female. Female rats were got into sexual receptivity via subcutaneous injection of $10 \mu \mathrm{g}$ estradiol benzoate dissolved in $100 \mu \mathrm{l}$ oil before sexual trial by $44 \mathrm{~h}$. Then, $1 \mathrm{mg}$ of progesterone / $200-\mu \mathrm{l}$ oil was subcutaneously injected for females four $\mathrm{h}$ before testing. The test continued for $30 \mathrm{~min}$ after the female presentation, and the many indicators were documented. Latencies to the first mount, the first intromission, and the first ejaculation were recorded. The number of mounts (mounts with pelvic thrusting) and intromissions (mounts with pelvic thrusting and penile insertion) of the first copulatory succession were counted. Furthermore, the frequency of ejaculation (ejaculation number throughout $30 \mathrm{~min}$ of recording) and post-ejaculatory interval (time between ejaculation and following intromission) were documented (Hull et al. 2006). The observations were recorded using a video camera connected to a monitor in a neighboring room.

\subsection{Semen evaluation}

Evaluation of semen was carried out as previously reported by (Arisha \&Moustafa 2019). Briefly, The cauda epididymis was extracted from one testis and macerated in a petri dish containing $2 \mathrm{ml}$ of prewarmed physiological saline solution at $37^{\circ} \mathrm{C}$ (Hafez 1970). To determine the individual motility of the spermatozoa, one drop of the resultant solution was directly examined under a light microscope on prewarmed glass slides with a magnification of $400 x$. The total percentage of motile sperm was measured in numerous microscopic fields. Total sperm count was estimated following dilution with physiological 
saline at 1:4 with addition of 5 drop of formalin ( $40 \%)$ solution. The total sperm count was calculated as the sum of spermatozoa counted in five secondary square $\times 2500 \times$ dilution rate. Sperm abnormalities were detected in eosin-nigrosine stained slides and counted per 100 sperm (Filler 1993, Seed et al. 1996)

\subsection{Blood and tissue sampling}

After 65 days, the rats were weighed and fasted overnight. From the medial canthus of the eye, blood samples were collected into a plain tube, permitted to coagulate for 30 minutes, and centrifuged at 3000 rpm for 10 minutes to separate serum for further biochemical evaluations. Following this, the rats were euthanized by cervical dislocation. Then the testes were directly excised and weighed. Samples from the testis were divided into three portions. The first part homogenized in phosphate-buffered saline,

centrifuged for 15 minutes at $3000 \times g$, then the collected supernatant was kept frozen for oxidative stress markers analysis. The second portion was kept for histopathological screening after fixing in phosphatebuffered formalin $10 \%$. The third portion was kept for gene expression investigations in liquid nitrogen at $-80^{\circ} \mathrm{C}$.

\subsection{Serum hormonal assay and testicular enzymes}

Testesterone, luteinizing hormone (LH), follicular stimulating hormone (FSH) and estradiol (E2) activities were detected using enzyme-linked immunosorbent assay (ELISA) kits (MyBioSource, California, USA, Catalog No: MBS9424769, MBS263466, MBS703380 and MBS700807, respectively) according to the manufacturer's guidelines. Sorbitol dehydrogenase (SDH) and Acid phosphatase (ACP) enzymes were assayed using ELISA kits (MyBioSource, California, USA Catalog No: MBS2023295 and MBS046840 respectively) following the manufacturer's directives.

\subsection{Measurement of oxidative stress and apoptosis biomarkers in testis homogenates}

Total antioxidant capacity (TAC) was evaluated using the colorimetric technique, as described by Koracevic et al. (2001). Glutathione peroxidase (GPx) was assessed, according to Pascual et al. (1992). Reduced glutathione (GSH) level was determined according to the method described by Beutler et al. (1963). Malondialdehyde (MDA) was measured, according to Esterbauer et al. (1982). B-cell CLL/lymphoma 2 (Bcl2) and Caspase 3 were quantitated using ELISA Kit (MyBioSource, San Diego, California, USA, Catalog No: MBS704330 and MBS700575, respectively) in line with the manufacturer's directions.

\subsection{Histopathological examination and histomorphometric analysis}

All tissue samples, including testes, cauda epididymis, prostate and seminal vesicles were kept in formalin solution $10 \%$ and subsequently dehydrated, cleared in xylene, embedded, and blocked in paraffin using an automatic tissue processor. Then, $5 \mu \mathrm{m}$ thickness sections were cut by a rotary microtome and finally stained by hematoxylin and eosin (H \& E) (Suvarna et al. 2018). Five sections from each organ per 
animal were examined under the light microscopy (Olympus, Tokyo, Japan) at different magnifications to detect qualitative histological changes and histomorphometric assessments.

Cross-sections of the seminiferous tubules were randomly chosen from each rat to measure germinal epithelium height (GEH), seminiferous tubules diameter (STD), tubular lumen diameter (TLD), tunica propria thickness, and testicular capsule thickness (TCT) (Babazadeh \&Najafi 2017, Ibrahim et al. 2016). The epididymal tissue sections were examined for epididymal epithelial height (EEH), epididymal ductular diameter (EDD), and epididymal luminal diameter (ELD)(Awobajo et al. 2010). Epithelial height and smooth muscle layer thickness (SMT) were estimated in the prostate gland sections (Sakr et al. 2012). The mean epithelial height and fibro-muscular layer thickness (FMT) were measured in the seminal vesicles sections from each rat (Justulin et al. 2006). All these parameters were measured $(\mu \mathrm{m})$ in 30 different fields from each tissue section per each animal at 100x and $400 \times$ to calculate a mean value.

\subsection{Quantitative real-time PCR}

Using the RNeasy Mini Kit, the testicular total RNAs were extracted according to the manufacture guidelines. Total RNA was converted to cDNA using RevertAid Reverse Transcriptase (Thermo Fisher, catalog number: EP0441). Quantification of NR5A1, HSD $17 B_{3}$, SIRT1, TERT and PGC-1a mRNAs gene expression was conducted using Quantitect SYBR green PCR kit. Using Mx3005P Real-Time PCR System (Agilent Stratagene, USA), the PCR was conducted at $95^{\circ} \mathrm{C}$ for $15 \mathrm{~min}$. followed by 40 cycles of $94^{\circ} \mathrm{C}$ for $15 \mathrm{~s}, 60^{\circ} \mathrm{C}$ for $30 \mathrm{~s}$, and $72^{\circ} \mathrm{C}$ for $30 \mathrm{~s}$. The target is normalized to an endogenous reference gene (glyceraldehyde-3-phosphate dehydrogenase (GAPDH)), and the relative fold changes in gene expression were determined following the $2^{-\triangle \Delta C T}$ comparative method (Livak \&Schmittgen 2001). The primers sequences of analyzed genes were listed in Table 1. 
Table 1

Oligonucleotide primer sequences and real-time PCR conditions:

\begin{tabular}{|c|c|c|c|c|}
\hline $\begin{array}{l}\text { Gene } \\
\text { name }\end{array}$ & $\begin{array}{l}\text { Accession } \\
\text { number }\end{array}$ & & Primer sequences ( $5^{\prime}$ to $3^{\prime}$ ) & Product size (bp) \\
\hline \multirow[t]{2}{*}{ GAPDH } & \multirow[t]{2}{*}{ NM_ 017008.4} & $\mathrm{~F}$ & 5'-AAAGGGTCATCATCTCCGCC-3' & \multirow[t]{2}{*}{197} \\
\hline & & $\mathrm{R}$ & 5'-AGTGATGGCATGGA CTGTGG-3' & \\
\hline \multirow[t]{2}{*}{ NR5A1 } & \multirow[t]{2}{*}{ NM_001191099.1 } & $\mathrm{F}$ & 5'-ATTCCTGAACAACCACAGCC - 3' & \multirow[t]{2}{*}{131} \\
\hline & & $\mathrm{R}$ & 5'-ACCTCCACCAGGCACAATAG - 3' & \\
\hline \multirow[t]{2}{*}{ HSD17B3 } & \multirow[t]{2}{*}{ NM_054007 } & $\mathrm{F}$ & 5'- GAAAGTTGGTGTTCGGCTGAAG-3' & \multirow[t]{2}{*}{202} \\
\hline & & $\mathrm{R}$ & 5'- CCACAAGCCAATACAAACTAACT - 3' & \\
\hline \multirow[t]{2}{*}{ SIRT1 } & \multirow[t]{2}{*}{ NM_001372090.1 } & $\mathrm{F}$ & 5'- AGCTGGGGTTTCTGTTTCCT - 3' & \multirow[t]{2}{*}{224} \\
\hline & & $\mathrm{R}$ & 5'- TGCTGAGTTGCTGGATTTTG - 3' & \\
\hline \multirow[t]{2}{*}{ TERT } & \multirow[t]{2}{*}{ NM_053423.1 } & $\mathrm{F}$ & $\begin{array}{l}\text { 5'- GACATGGAGAACAAGCTGTTTGC - } \\
3^{\prime}\end{array}$ & \multirow[t]{2}{*}{185} \\
\hline & & $\mathrm{R}$ & 5'- ACAGGGAAGTTCACCACTGTC - 3' & \\
\hline \multirow[t]{2}{*}{ PGC-1a } & \multirow[t]{2}{*}{ NM_031347.1 } & $\mathrm{F}$ & 5'- AGGTCCCCAGGCAGTAGAT - 3' & \multirow[t]{2}{*}{128} \\
\hline & & $\mathrm{R}$ & 5'- CGTGCTCATTGGCTTCATA - 3' & \\
\hline $\begin{array}{l}\text { F indicate } \\
\text { member } \\
\text { type-1; TE } \\
\text { gamma o }\end{array}$ & $\begin{array}{l}\text { ward primer; } \mathbf{R} \\
\text { I7B3 hydroxyste } \\
\text { omerase reverse } \\
\text { ator 1-alpha }\end{array}$ & & $\begin{array}{l}\text { reverse primer; NR5A1 Nuclear recept } \\
\text { a dehydrogenase 3; SIRT1 Silent info } \\
\text { ase; PGC-1a Peroxisome proliferator-a }\end{array}$ & $\begin{array}{l}\text { bfamily group } \mathrm{A} \text {, } \\
\text { ion regulator } \\
\text { ated receptor }\end{array}$ \\
\hline
\end{tabular}

\subsection{Statistical Analysis}

Statistical analysis was performed by a computer program (SPSS, version 20). Data were set as mean \pm standard error (SE). The comparisons were performed using a one-way analysis of variance (ANOVA) test followed by Tukey Multiple Range test. The results indicate a statistical significance when $P$ value $<0.05$.

\section{Results}

\subsection{Effects on sexual behavior}

Data on sexual behavior evaluation are displayed in Table 2. Exposure to IPR alone induced a significant delay in the mounting latency and inter intromission interval compared with the control group. At the same time, mount and ejaculation latencies, ejaculation frequency together with post-ejaculatory inter intromission intervals, were significantly increased in rats exposed to CPF alone compared to the control. Notably, the co-exposure group showed a significant increase in mount, intromission, and ejaculation latencies, ejaculation frequency, and post-ejaculatory inter intromission intervals in relation to the control 
group. The intromission ratio was significantly reduced in all the treated groups compared to the control one. Nevertheless, both mount and intromission frequencies were not significantly changed among the different treated groups.

\section{Table 2}

Effect of iprodione (IPR) and/or chlorpyrifos (CPF) exposure on sexual behaviour of adult male Sprague Dawely rats.

\begin{tabular}{|c|c|c|c|c|}
\hline & Experimental grou & & & \\
\hline & Control & IPR & CPF & IPR + CPF \\
\hline $\mathrm{ML}(\mathrm{sec})$ & $112.86 \pm 10.25^{c}$ & $214.67 \pm 26.20^{b}$ & $353.83 \pm 46.16^{a}$ & $402.83 \pm 25.83^{a}$ \\
\hline MF & $12.71 \pm 1.99$ & $14.00 \pm 1.06$ & $17.00 \pm 2.20$ & $16.33 \pm 2.44$ \\
\hline $\mathrm{IL}(\mathrm{sec})$ & $340.14 \pm 68.96^{b}$ & $392.0 \pm 3.34^{b}$ & $440.0 \pm 25.77^{b}$ & $638.33 \pm 36.44^{a}$ \\
\hline IF & $20.28 \pm 3.41$ & $17.33 \pm 0.88$ & $17.83 \pm 1.66$ & $17.33 \pm 0.9$ \\
\hline $\mathrm{EL}(\mathrm{sec})$ & $897.14 \pm 129.56^{c}$ & $1278.7 \pm 71.69^{b c}$ & $1360.8 \pm 81.18^{a b}$ & $1583.3 \pm 35.97^{a}$ \\
\hline EF & $2.14 \pm 0.4^{a}$ & $1.5 \pm 0.22^{\mathrm{ab}}$ & $0.83 \pm 0.16^{b c}$ & $0.33 \pm 0.21^{c}$ \\
\hline PEI(sec) & $258.14 \pm 17.0^{b}$ & $346.0 \pm 32.88^{b}$ & $496.83 \pm 24.87^{a}$ & $593.0 \pm 62.84^{a}$ \\
\hline IR & $0.60 \pm 0.012^{a}$ & $0.55 \pm 0.02^{b}$ & $0.51 \pm 0.02^{b}$ & $0.50 \pm 0.022^{b}$ \\
\hline III & $50.79 \pm 7.35^{b}$ & $74.13 \pm 4.96^{a}$ & $76.8 \pm 3.95^{a}$ & $78.47 \pm 4.41^{\mathrm{a}}$ \\
\hline $\begin{array}{l}\text { Means w } \\
\text { shown al }\end{array}$ & $\begin{array}{l}\text { the same row } \mathrm{ce} \\
\text { ans } \pm \text { SE. } n=10\end{array}$ & ifferent supers & significant di & $p<0.05$. Values \\
\hline $\mathrm{ML}=\mathrm{Mo}$ & latency, time from i & duction to the fema & ntil the first mount & \\
\hline $\mathrm{MF}=\mathrm{Mo}$ & frequency: number & lounts & & \\
\hline $\mathrm{IL}=$ IntroI & sion latency, time fr & ntroduction to the & ale until the first int & ission \\
\hline $\mathrm{IF} ;=$ Intro & ssion frequency: nu & of intromissions & & \\
\hline $\begin{array}{l}\mathrm{EL}=\mathrm{Ejac} \\
\text { number } \mathrm{c}\end{array}$ & $\begin{array}{l}\text { tion latency, time frc } \\
\text { jaculations }\end{array}$ & e first intromissior & jaculationEF = Eja & ion frequency: \\
\hline $\mathrm{PEI}=\mathrm{Pos}$ & aculatory interval; t & rom ejaculation un & ext intromission & \\
\hline $\begin{array}{l}\mathrm{IR}=\text { Intro } \\
\text { intromiss }\end{array}$ & $\begin{array}{l}\text { sion ratio; the numb } \\
\text { is and the number }\end{array}$ & $\begin{array}{l}\text { f intromissions divi } \\
\text { unts }\end{array}$ & by the sum of the & ber of \\
\hline $\begin{array}{l}\text { III = Inter } \\
\text { ejaculat }\end{array}$ & $\begin{array}{l}\text { nission interval; } \\
\text { ency divided by }\end{array}$ & $\begin{array}{l}\text { l test time divide } \\
\text { nber of intromiss }\end{array}$ & he number of in & ons, or the \\
\hline
\end{tabular}




\subsection{Effects on body weight, testis weight, and sperm parameters}

As documented in Table 3, oral dosing of IPR, CPF, and their combination for 65 days triggered significant decrease in the body weight change, and testis weight compared to the control group. Moreover, the gonadosomatic index was significantly reduced in IPR and IPR + CPF exposed rats.

Table 3

Effect of iprodione (IPR) and/or chlorpyrifos (CPF) exposure on body weight change, gonadosomatic index, and sperm characteristics of adult male Sprague Dawely rats.

\begin{tabular}{|c|c|c|c|c|}
\hline & \multicolumn{4}{|c|}{ Experimental groups } \\
\hline & Control & IPR & CPF & IPR + CPF \\
\hline Initial Body weight (g) & $153.8 \pm 0.86$ & $153.8 \pm 0.58$ & $154 \pm 0.86$ & $154.5 \pm 1.04$ \\
\hline Final body weight (g) & $284.2 \pm 2.75^{\mathrm{a}}$ & $268.4 \pm 2.64^{b}$ & $260.8 \pm 3.89^{b c}$ & $251.3 \pm 3.04^{c}$ \\
\hline Body weight change (g) & $130.4 \pm 2.84^{\mathrm{a}}$ & $114.8 \pm 3.61^{b}$ & $106.8 \pm 3.9 b^{c}$ & $96.8 \pm 3.09^{c}$ \\
\hline Testes weight (g) & $1.55 \pm 0.06^{\mathrm{a}}$ & $1.02 \pm 0.12^{b}$ & $1.16 \pm 0.06^{b}$ & $0.9 \pm 0.03^{b}$ \\
\hline Gonadosomatic index (\%) & $0.55 \pm 0.02^{\mathrm{a}}$ & $0.38 \pm 0.05^{b}$ & $0.44 \pm 0.03^{\mathrm{ab}}$ & $0.36 \pm 0.01^{b}$ \\
\hline Sperm count $\left(\times 10^{6} / \mathrm{mL}\right)$ & $97.33 \pm 3.84^{\mathrm{a}}$ & $63.67 \pm 3.84^{b}$ & $61.33 \pm 3.48^{\mathrm{b}}$ & $53.33 \pm 6.44^{b}$ \\
\hline Sperm motility (\%) & $94.33 \pm 2.33^{a}$ & $58.33 \pm 4.41^{\mathrm{b}}$ & $41.67 \pm 3.33^{c}$ & $35.3 \pm 2.89^{c}$ \\
\hline Sperm abnormalities (\%) & $14.33 \pm 1.45^{c}$ & $38.33 \pm 1.86^{\mathrm{b}}$ & $44.67 \pm 1.45^{b}$ & $53 \pm 1.53^{a}$ \\
\hline
\end{tabular}

The sperm motility percentage and sperm count of IPR, CPF, and IPR + CPF groups showed a significant reduction compared with the control group. However, sperm abnormalities\% increased significantly increased in rats individually or simultaneously exposed to IPR and CPF compared to control rats. Notably, the IPR + CPF group showed a significant difference in sperm abnormalities \% compared with IPR or CPF exposed groups. These morphological alterations comprise a detached tail, looped tail, abnormal hookless head, coiled tail, curved tail, detached head, bent neck, bent neck with a hookless head, as demonstrated in Fig. 1.

\subsection{Effects on serum hormonal profile and testicular enzymes}

The obtained data in Table 4 showed that serum Testosterone, LH, FSH and E2 were significantly reduced in rats individually or concurrently exposed to IPR and CPF compared with control ones. Furthermore, 
serum ACP and SDH levels in all the treated rats were significantly decreased compared with control rats.

Table 4

Effect of iprodione (IPR) and/or chlorpyrifos (CPF) exposure on hormonal variables, testicular enzymes, antioxidant activity, and apoptotic indicators of adult male Sprague Dawely rats.

\begin{tabular}{|c|c|c|c|c|}
\hline & \multicolumn{4}{|c|}{ Experimental groups } \\
\hline & Control & IPR & CPF & IPR + CPF \\
\hline \multicolumn{5}{|l|}{ Serum } \\
\hline Testosterone $(\mathrm{ng} / \mathrm{mL})$ & $3.74 \pm 0.21^{a}$ & $2.77 \pm 0.11^{b}$ & $1.65 \pm 0.30^{c}$ & $1.01 \pm 0.15^{c}$ \\
\hline $\mathrm{LH}(\mathrm{mIU} / \mathrm{mL})$ & $41.56 \pm 1.21^{a}$ & $32.31 \pm 1.79^{b}$ & $25.20 \pm 2.21^{c}$ & $18.54 \pm 1.54^{d}$ \\
\hline $\mathrm{FSH}(\mathrm{mlU} / \mathrm{mL})$ & $7.13 \pm 0.07^{a}$ & $6.42 \pm 0.19^{a}$ & $4.6 \pm 0.23^{b}$ & $0.72 \pm 0.10^{c}$ \\
\hline $\mathrm{E} 2(\mathrm{pg} / \mathrm{mL})$ & $108.02 \pm 2.40^{a}$ & $86.64 \pm 3.03^{b}$ & $70.71 \pm 3.37^{c}$ & $54.92 \pm 2.95^{d}$ \\
\hline $\operatorname{ACP}(U / L)$ & $20.67 \pm 1.26^{\mathrm{a}}$ & $16.97 \pm 0.15^{a b}$ & $14.17 \pm 0.64^{b}$ & $9.5 \pm 0.29^{c}$ \\
\hline $\mathrm{SDH}(\mathrm{ng} / \mathrm{mL})$ & $1.77 \pm 0.46^{a}$ & $0.74 \pm 0.08^{a b}$ & $0.62 \pm 0.04^{b}$ & $0.41 \pm 0.06^{b}$ \\
\hline \multicolumn{5}{|l|}{ Testis homogenates } \\
\hline TAC (mmol/g protein) & $0.92 \pm 0.004^{a}$ & $0.87 \pm 0.003^{b}$ & $0.78 \pm 0.004^{c}$ & $0.75 \pm 0.003^{d}$ \\
\hline GSH (mmol/ g protein) & $3.91 \pm 0.02^{\mathrm{a}}$ & $2.79 \pm 0.02^{b}$ & $2.06 \pm 0.03^{c}$ & $1.77 \pm 0.01^{d}$ \\
\hline GPx (ng/mg protein) & $143.37 \pm 4.47^{\mathrm{a}}$ & $115.23 \pm 3.09^{b}$ & $91.9 \pm 2.33^{c}$ & $77.83 \pm 4.37^{d}$ \\
\hline MDA (nmol/g protein) & $11.22 \pm 0.03^{d}$ & $14.1 \pm 0.21^{\mathrm{c}}$ & $15.97 \pm 0.26^{b}$ & $16.8 \pm 0.17^{\mathrm{a}}$ \\
\hline Caspase-3(ng/mg protein) & $1.00 \pm 0.06^{c}$ & $1.01 \pm 0.02^{\mathrm{c}}$ & $1.16 \pm 0.04^{b}$ & $1.54 \pm 0.03^{\mathrm{a}}$ \\
\hline Bcl-2 (ng/mg protein) & $0.76 \pm 0.005^{a}$ & $0.66 \pm 0.004^{b}$ & $0.54 \pm 0.003^{c}$ & $0.46 \pm 0.003^{d}$ \\
\hline \multicolumn{5}{|c|}{$\begin{array}{l}\text { LH: luteinizing hormone; FSH: follicle-stimulating hormone; E2: estradiol; ACP: acid phosphatise; LDH } \\
\text { lactate dehydrogenase enzyme: TAC: total antioxidant capacity; GSH: reduced glutathione; GPX: } \\
\text { glutathione peroxidase; MDA: malondialdehyde; Bcl-2: b cell lymphoma-2. Means within same row } \\
\text { carrying different superscripts are significant different at } p<0.05 \text {. Values shown are means } \pm \text { SE. } \mathrm{n}= \\
10 \text { group. }\end{array}$} \\
\hline
\end{tabular}

\subsection{Effects on oxidative stress and apoptosis markers}

The administration of IPR, CPF, and IPR + CPF lead to a significant reduction in the TAC, GSH, and GPx levels but a substantial increase in the MDA level compared to the control values. Regarding the apoptotic markers, the obtained data demonstrated a significant increase in Caspase 3 levels; while Bcl-2 was significantly decreased especially in IPR + CPF group.

\subsection{Histopathological findings}




\subsubsection{Testicular tissue}

The testicular tissue of control rats revealed well-developed seminiferous tubules with active spermatogenesis at different stages of germinal cell differentiation and maturation. There were prominent interstitial Leydig cells. On the other side, testicular tissue sections of IPR and CPFadministered rats showed testicular alterations with spermatogenesis interruption. These alterations were more prominent in the CPF-administered group, which were represented by degenerative changes of spermatogenic and Sertoli cells accompanied by lumen contraction and thickened and corrugated basement membrane. There were desquamated germ cells with few sperm cells and little debris of spermatids in their lumen. Wide spaces separated between the degenerated germinal epithelium and the basement membrane inside the seminiferous tubules appeared. Besides, the co-exposed group showed severe tubular damages as degenerative changes and desquamation of their germinal epithelium associated with no or few spermatogenic cells in the atrophied tubules, leading to complete cessation of spermatogenesis.

Moreover, all treated groups showed vacuolar degenerated Leydig cells associated with leucocytic infiltrations in the interstitial tissues in different degrees. There was apparent interstitial blood vessel dilatation and congestion. General interstitial and sub-scapular edema were noticed that leading to wide vacuolated intertubular spaces. The testicular parenchyma was covered by a thick testicular capsule that contained congested blood vessels (Fig. 2A-G).

\subsubsection{Epididymis tissues}

The examined sections of the control group showed normal tubular structure filled with a dense aggregation of sperms by light microscopy. On the other side, examining all treated rats' cauda epididymis revealed that tubular irregularity and lined with flat epithelial cells. There was vacuole formation with disrupted stereocilia. Epithelial inflammation and necrosis in the epididymis were noted. There were marked pathological changes especially rats treated with CPF or with IPR. These changes included degeneration and cytoplasmic vacuolation with desquamated stereocilia of the principal cells. Hypertrophy of the clear cells with a degenerated nucleus and increased vesicles were showed. Also, there was growth in halo cells with hypertrophy. In addition, a broken basement membrane with destructed tubules appeared. Increased cell debris and abnormal round germ cells associated with reduction or absence of spermatozoa density appeared in the epididymis lumen. The hypertrophied intertubular connective tissue had congested blood vessels, lymphocytic infiltrations, and edema. Moreover, thickened smooth muscle layers between the tubules were noted. The capsule was showed thickness accompanied by blood vessel congestion and subcapsular edema (Fig. 3A-G).

\subsubsection{Prostate gland tissues}

The prostate glands of the control group revealed no histopathological alterations. They appeared with normal acini enclosed in an outer capsule and filled with pink secretion. The different treated materials induced several histopathological changes associated with irregular acinar shape and size. The glandular 
tissues showed a marked degree of epithelial hyperplasia in most of the acini accompanied with papillary projections, and other alveoli were enlarged with abnormal flattened epithelium. This hyperplasia was more prominent in both groups that treated with IPR or CPF alone. On the other side, there was marked epithelial hyperplasia and papillary projections accompanied by acinar shrinkage and narrow lumen in IPR and CPF-treated rats. Moreover, there were epithelial degeneration and necrosis, as well as luminal cellular debris. Thick fibro-muscular stroma accompanied by vacuolations surrounded the acini in most of the examined glands. It was remarkable that interstitial spaces showed interstitial edema, blood vessels congestion, and vasculitis. There were hemorrhages and monocellular inflammatory cells infiltration inside the acinar lumen and around the acini. There were marked edema, hemorrhages and congested blood vessels in the prostatic capsule (Fig. 4A-G).

\subsubsection{Seminal vesicle tissues}

The seminal vesicles of the control group appeared normal. They showed epithelial folds that lined with columnar epithelium and basal cells. A fibro-muscular layer followed this layer, and the gland was enclosed with a capsule. A secretion was visible in the gland lumen. While treated groups with IPR and CPF showed gland hyperplasia with papillary structures compared to those of control rats. Vacuolar degeneration and detached epithelium were noticed. A remarkable increase in gland secretions in the dilated lumen was also evident. On the other side, the seminal vesicles of IPR and CPF rats revealed that glandular atrophy with destructed folds and scanty fluid in their lumen. Also, the fibro-muscular layer of all treated groups showed edema with inflammatory cell infiltrations, mainly lymphocytes, and macrophages. There was blood vessel congestion accompanied by vasculitis. Vacuolar degeneration of this layer was prominent. Marked subcapsular edema was observed (Fig. 5A-F).

\subsection{Morphometric analysis of testis and accessory glands 3.6.1. Morphometric analysis of testis}

As shown in Table 5, seminiferous tubules diameter was significantly decreased in the treated groups, especially in CPF group. It was observed that the testicular GEH and TLD values were significantly decreased in all treated groups. While testicular capsule thickness was highly increased in all treated groups compared to the control. 
Table 5

Effect of iprodione (IPR) and/or chlorpyrifos (CPF) exposure on morphometric analysis of the testis and accessory glands of adult male Sprague Dawely rats.

\begin{tabular}{|c|c|c|c|c|c|}
\hline \multirow[t]{2}{*}{ Organ } & \multirow{2}{*}{$\begin{array}{l}\text { Morphometric parameter } \\
(\mu \mathrm{m})\end{array}$} & \multicolumn{4}{|c|}{ Experimental groups } \\
\hline & & Control & IPR & $\mathrm{CPF}$ & $\mathrm{IPR}+\mathrm{CPF}$ \\
\hline \multirow[t]{5}{*}{ Testis } & $\begin{array}{l}\text { Seminiferous tubules } \\
\text { diameter STD }\end{array}$ & $\begin{array}{l}221.33 \pm \\
6.81^{\mathrm{a}}\end{array}$ & $\begin{array}{l}179.67 \pm \\
14.3^{b}\end{array}$ & $\begin{array}{l}98 \pm \\
20.97^{c}\end{array}$ & $\begin{array}{l}110.67 \pm \\
11.02^{\mathrm{C}}\end{array}$ \\
\hline & $\begin{array}{l}\text { Germinal epithelium height } \\
\text { GEH }\end{array}$ & $63.33 \pm 7.57^{a}$ & $\begin{array}{l}51.67 \pm \\
1.16^{\mathrm{b}}\end{array}$ & $\begin{array}{l}26.33 \pm \\
1.16^{c}\end{array}$ & $\begin{array}{l}24.67 \pm \\
4.51^{\mathrm{c}}\end{array}$ \\
\hline & $\begin{array}{l}\text { Tubular lumen diameter } \\
\text { TLD }\end{array}$ & $\begin{array}{l}103.01 \pm \\
14.2^{\mathrm{a}}\end{array}$ & $\begin{array}{l}78.67 \pm \\
17.67^{\mathrm{ab}}\end{array}$ & $\begin{array}{l}54.33 \pm \\
13.65^{b}\end{array}$ & $\begin{array}{l}42.33 \pm \\
8.02^{\mathrm{C}}\end{array}$ \\
\hline & $\begin{array}{l}\text { Testicular capsule } \\
\text { thickness TCT }\end{array}$ & $36.02 \pm 4.02^{b}$ & $\begin{array}{l}56.01 \pm \\
5.29^{\mathrm{b}}\end{array}$ & $\begin{array}{l}88.67 \pm \\
26.27^{a}\end{array}$ & $\begin{array}{l}115.02 \pm \\
13.75^{\mathrm{a}}\end{array}$ \\
\hline & Tunica propria thickness & \pm 2.086 .33 & $\begin{array}{l}7.67 \pm \\
1.53\end{array}$ & $\begin{array}{l}8.02 \pm \\
1.01\end{array}$ & $\begin{array}{l}9.33 \pm \\
1.53\end{array}$ \\
\hline \multirow[t]{3}{*}{ Epididymis } & $\begin{array}{l}\text { Epididymal ductular } \\
\text { diameter EDD }\end{array}$ & $\begin{array}{l} \pm \\
11.02^{\mathrm{b}} 258.67\end{array}$ & $\begin{array}{l}292.33 \pm \\
4.04^{\mathrm{a}}\end{array}$ & $\begin{array}{l}290 \pm \\
9.54^{\mathrm{a}}\end{array}$ & $\begin{array}{l}280.67 \pm \\
9.71^{\mathrm{a}}\end{array}$ \\
\hline & $\begin{array}{l}\text { Epididymal luminal } \\
\text { diameter ELD }\end{array}$ & $\begin{array}{l}239.67 \pm \\
7.51^{\mathrm{b}}\end{array}$ & $\begin{array}{l}274.01 \pm \\
11.53^{\mathrm{a}}\end{array}$ & $\begin{array}{l}286.33 \pm \\
10.12^{\mathrm{a}}\end{array}$ & $\begin{array}{l}278.67 \pm \\
15.04^{\mathrm{a}}\end{array}$ \\
\hline & $\begin{array}{l}\text { Epididymal epithelial } \\
\text { height EEH }\end{array}$ & $\begin{array}{l}19.67 \pm \\
2.31^{\mathrm{ab}}\end{array}$ & $\begin{array}{l}15.33 \pm \\
2.52^{\mathrm{c}}\end{array}$ & $\begin{array}{l}21.33 \pm \\
2.08^{\mathrm{a}}\end{array}$ & $\begin{array}{l}16.67 \pm \\
1.53 b^{c}\end{array}$ \\
\hline \multirow[t]{2}{*}{ Prostate } & Epithelial height & $\pm 3.22^{b} 21.33$ & $\begin{array}{l}27.03 \pm \\
4.36^{\mathrm{a}}\end{array}$ & $\begin{array}{l}29.67 \pm \\
2.08^{a}\end{array}$ & $\begin{array}{l}20.33 \pm \\
1.53^{b}\end{array}$ \\
\hline & $\begin{array}{l}\text { Smooth muscle layer } \\
\text { thickness SMT }\end{array}$ & $\pm 1.16^{c} 25.67$ & $\begin{array}{l}29.67 \pm \\
4.61 b^{c}\end{array}$ & $\begin{array}{l}33.02 \pm \\
3^{\mathrm{ab}}\end{array}$ & $\begin{array}{l}37.02 \pm \\
3.61^{\mathrm{a}}\end{array}$ \\
\hline \multirow[t]{2}{*}{$\begin{array}{l}\text { Seminal } \\
\text { Vesicle }\end{array}$} & Epithelial height & $22.33 \pm 3.06$ & $\begin{array}{l}29.33 \pm \\
2.08\end{array}$ & $\begin{array}{l}29.67 \pm \\
10.02\end{array}$ & $\begin{array}{l}25.33 \pm \\
5.03\end{array}$ \\
\hline & $\begin{array}{l}\text { Fibro-muscular layer } \\
\text { thickness FMT }\end{array}$ & $\begin{array}{l}128.05 \pm \\
3.01^{\mathrm{b}}\end{array}$ & $\begin{array}{l}131.67 \pm \\
9.61^{\mathrm{b}}\end{array}$ & $\begin{array}{l}138.67 \pm \\
2.52^{\mathrm{b}}\end{array}$ & $\begin{array}{l}150.33 \pm \\
8.62^{a}\end{array}$ \\
\hline
\end{tabular}

\subsubsection{Morphometric analysis of epididymis, prostate, and seminal vesicles}

The epididymis tubular diameter and length was significantly increased in all the treated groups. The EEH was significantly increased in CPF group while decreased in IPR and combination groups. Prostate epithelium height was slightly increased in IPR group and CPF group while decreased in the combination 
group. SMT of prostate was significantly increased in all treated groups. Seminal vesicle epithelial height and FMT was increased in all treated groups especially in the combination group (Table 5).

\subsection{Gene expression findings}

As shown in Fig. 6, a significant down-regulation of NR5A1 and HSD17B3 mRNA levels in all treated groups and was obvious in IPR + CPF co-exposed group. All treated groups showed a significant downregulation of the SIRT1, TERT and PGC1 a mRNA levels than the control.

\section{Discussion}

In our study, the IPR and CPF oral dosing induced a significant reduction in the body weight gain and testis weight, particularly in the group exposed to a combination of IPR and CPF. Oxidative stress may play a role in reducing body weight (Mossa et al. 2015). Reproductive organ weights are sensitive measures of chemical-induced reproductive toxicity (Zidan 2009). The reduction of testicular weights may be due to reduced tubular size, as confirmed by the testis' histopathological findings. Also, inhibition of steroid biosynthesis of Leydig cells and arrest of spermatogenesis may be a possible cause of such reduction.

Herein, in rats exposed to IPR, a reduction in serum testosterone may be linked to the IPR imidazole-like ring. Many chemical compounds in the imidazole class inhibit steroidogenesis via one or more cytochrome P450s (Blystone et al. 2007). Furthermore, Rone et al. (2009) reported that IPR prevention of the movement of cholesterol from the external to the inner mitochondrial membrane might adversely affect the production of the sexual steroids. Besides, the sexual hormonal imbalance observed in CPF exposed rats may be owed to the direct degenerative effect on Leydig cells and/or indirectly via its nicotine-like suppressive activity on LH release from the pituitary gland as one of the acetylcholine receptors agonists (Peiris \&Dhanushka 2017, Rato et al. 2015). Testicular marker enzymes, namely ACP and SDH, are essential to healthy germ cell growth and are closely associated with spermatogenesis (Adedara et al. 2018a). The substantial decrease in testicular function marker enzymes in rats exposed to IPR and CPF suggests a reduction in the transport of testicular nutrients, energy metabolism, and division into sperm cells (Adedara et al. 2018b)

Concerning semen evaluation, the significant inhibition of sperm motility in all the exposed groups can be due to low ATP levels (Bai \&Shi 2002, Heikal et al. 2014). Also, LH is essential for the functional epididymal maturation and acquisition of progressive $\mathrm{Ca}^{2+}$ motility through the absorption of specific bdefensin from the main cells. (Lehrer \&Lu 2012). The decrease in LH level could, therefore, lead to reduced sperm motility observed in this study. The reduction in sperm count of the treated rats in our study may be linked to the decrease in serum testosterone levels, resulting in the suppression of spermatogenesis (Sharma et al. 2014). In the testes, decreases in sperm counts can also be due to oxidative stress (Shittu et al. 2012). Sperm abnormalities are mainly hormone-dependent. So, the low testosterone level may be the critical factor producing sperm deformities (Guido et al. 2014). 
Notably, herein, exposure to IPR and CPF alone or in a combination considerably disturb sexual behavior as revealed by deferred latencies to the first mount, first intromission, and first ejaculation, in addition to diminished ejaculations number. In adult mammals, male sexual activity is modulated by TES (Robbins 1996); and it is controlled by the hypothalamic-pituitary-testicular axis (Ågmo 1997). In this way, it is proposed that the reduced testosterone level could be responsible for the male sexual behavior disturbances noted in the current study. Male mammalian sexual behavior depends on the testosterone that Leydig cells release in testicles (Nakayama et al. 2018). Nevertheless, the only factor linked to behavioral disorders may not be low testosterone concentrations in adults. For example, additional potential factors should be considered, a reduction in brain responses to androgenic male sexual stimulation.

Current data indicated the reduction of antioxidants (TAC and GPx) and non-enzyme antioxidant (GSH) activity. Still, they increased MDA content in testicular tissues of IPR and/or CPF treated rats has occurred. Similarly, Zhang et al. (2020) showed that 70 days of intragastric CPF dosing substantially increased the relative sperm ROS levels in C57BL/ 6 mice. Also, IPR produced oxidative damage in the HepG2 cell line (Radice et al. 1998) and primary cultured fish hepatocytes (Radice et al. 2001). A significant increase in the Caspase-3 and a significant decrease in Bcl-2 levels in the testicular tissue of IPR and/or CPF treated rats were observed in the present study. Therefore, seminal oxidative stress and apoptosis are interlinked in the IPR and CPF induced male infertility.

In this context, there was a significant reduction in of SIRT1, TERT and PGC1a expression concomitant with transcriptions factor that regulated enzymes in the steroidogenic pathway (NR5A1 and HSD17B3) (Anamthathmakula et al. 2019, Payne 1996) was evident following the exposure of rats to IPR and/or CPF for 65 days. Also, a concomitant decrease of the steroidogenic enzymes (SDH and ACP) has been associated with these steroidogenic genes' reduced transcriptional activity. In the postnatal stages, SIRT1 controls spermatogenesis with hypothalamus-pituitary gonadotropin signaling regulation (KolthurSeetharam et al. 2009). It has also been described to sense the redox shifts and incorporated into the metabolic process of mitochondria (Vachharajani et al. 2016). Excessively ROS can minimize activities of SIRT1. In male germline stem cells, this raises the intracellular NAD+/NADH ratio (He et al. 2017, Lin et al. 2018). Thus, the IPR and CPF induced oxidative stress could possibly disturb apoptosis and steroidogenesis related gene expression in the spermatogenic cells. These results help clarify that IPR and $\mathrm{CPF}$ induced male reproductive toxicity.

Of note, a synergistic outcome was recorded with IPR and CPF co-exposure in most of the estimated parameters. Similar synergistic interaction exists between CPF and other pesticides like imidacloprid (Xu et al. 2020) and permethrin (Yang \&Lai 2019). Such antagonism could be associated with the over-thegeneration ROS inducing more suppression of the SIRT1/TERT/PGC1a pathway to bring about synergism. In this context, (Ma et al. (2019)) indicated that androgenic antagonistic pesticide mixtures could act mutually at the receptor level.

\section{Conclusion}


In conclusion, our findings demonstrated the detrimental impacts of the single or combined exposure to IPR and CPF on the male sexual behavior and male reproductive system function and architecture. Besides, our findings afford a distinctive and intriguing perspective that excessive ROS generation following IPR and CPF exposure could promote steroidogenic genes downregulation and suppress SIRT1/TERT/PGC1a pathway. Such findings explain the target organelle and molecular mechanisms by which IPR and CPF contribute to animal and human impaired fertility.

\section{Declarations}

Author Contributions: Conceptualization: Yasmina M. Abd-Elhakim, Nabela I. El Sharkawy and Khlood M. El Bohy. Data Curation: Mona A. Hassan and Yasmina M. Abd-Elhakim. Formal Analysis: Mona A. Hassan. Methodology: Mona A. Hassan, Yasmina M. Abd-Elhakim and Tamer S. Imam. Histopathology: Abeer E. El-Metwally. Sexual behaviour assassment: Heba S.A. Gharib. Gene expression analysis: Ahmed Hamed Arisha .Writing Original draft: Yasmina M. Abd-Elhakim and Mona A. Hassan. Review and Editing: Yasmina M. Abd-Elhakim and Tamer S. Imam

\section{Acknowledgments:}

We thank all participants in this study.

\section{Data availability:}

The datasets used and/or analyzed during the current study are available from the corresponding author on reasonable request.

Funding: Not applicable

\section{Compliance with ethical standards:}

Conflicts of interests: The authors declare no conflicts of interest.

Ethical approval: The authors of the current study confirm that all the experimental procedures were conducted in strict compliance with the ethical standards of the $\mathrm{NIH}$ guidelines on the care and use of laboratory animals to minimize the suffering of the experimental animals throughout the acclimatization, experimentation, and sampling. The ethical standards were approved by the Institutional Animal Care and Use Committee of Zagazig University, Egypt (ZU-IACUC/2/F/41/2019).

Consent to participate: Not applicable

Consent for publication: Not applicable

\section{References}


1. Adedara IA, Alake SE, Adeyemo MO, Olajide LO, Ajibade TO, Farombi EO (2018a): Taurine enhances spermatogenic function and antioxidant defense mechanisms in testes and epididymis of L-NAMEinduced hypertensive rats. Biomed. Pharmacother. 97, 181-189

2. Adedara IA, Owoeye O, Ajayi BO, Awogbindin IO, Rocha JBT, Farombi EO (2018b): Diphenyl diselenide abrogates chlorpyrifos-induced hypothalamic-pituitary-testicular axis impairment in rats. Biochem. Biophys. Res. Commun. 503, 171-176

3. Ågmo A (1997): Male rat sexual behavior. Brain Research Protocols 1, 203-209

4. Ahmed M, Hashem DA, Ahmed SA, Khalid N (2019): Monitoring of Pesticide Residues in Cucumber Samples Marketed in Egypt. Journal of Plant Protection and Pathology 10, 225-228

5. Anamthathmakula P, Miryala CSJ, Moreci RS, Kyathanahalli C, Hassan SS, Condon JC, Jeyasuria P (2019): Steroidogenic Factor 1 (Nr5a1) is Required for Sertoli Cell Survival Post Sex Determination. Sci. Rep. 9, 4452

6. Angioni A, Dedola F, Garau A, Sarais G, Cabras P, Caboni P (2011): Chlorpyrifos residues levels in fruits and vegetables after field treatment. Journal of Environmental Science and Health, Part B 46, 544-549

7. Arisha AH, Moustafa A (2019): Potential inhibitory effect of swimming exercise on the KisspeptinGnRH signaling pathway in male rats. Theriogenology 133, 87-96

8. Awobajo FO, Raji Y, Akinloye AK (2010): Histomorphometric Changes in the Testes and Epididymis of Wistar Strain Albino Rats Following Fourteen Days Oral Administration of Therapeutic Doses of Some Antibiotics. International Journal of Morphology 28, 1281-1287

9. Babazadeh M, Najafi G (2017): Effect of chlorpyrifos on sperm characteristics and testicular tissue changes in adult male rats. Veterinary research forum : an international quarterly journal 8, 319-326

10. Bai J-P, Shi Y-L (2002): Inhibition of Ca2+ channels in mouse spermatogenic cells by male antifertility compounds from Tripterygium wilfordii Hook. f. Contraception 65, 441-445

11. Beutler E, Duron O, Kelly BM (1963): Improved method for the determination of blood glutathione. J. Lab. Clin. Med. 61, 882-8

12. Blystone CR, Lambright CS, Furr J, Wilson VS, Gray Jr LE (2007): Iprodione delays male rat pubertal development, reduces serum testosterone levels, and decreases ex vivo testicular testosterone production. Toxicol. Lett. 174, 74-81

13. Burke RD, Todd SW, Lumsden E, Mullins RJ, Mamczarz J, Fawcett WP, Gullapalli RP, Randall WR, Pereira EF, Albuquerque EX (2017): Developmental neurotoxicity of the organophosphorus insecticide chlorpyrifos: from clinical findings to preclinical models and potential mechanisms. J. Neurochem. $142,162-177$

14. Chaufan G, Galvano C, Nieves M, Mudry MD, Ríos de Molina MDC, Andrioli NB (2019): Oxidative Response and Micronucleus Centromere Assay in HEp-2 Cells Exposed to Fungicide Iprodione. Chem. Res. Toxicol. 32, 745-752

15. Coussens M, Maresh JG, Yanagimachi R, Maeda G, Allsopp R (2008): Sirt1 deficiency attenuates spermatogenesis and germ cell function. PLoS One 3, e1571 
16. Esterbauer H, Cheeseman KH, Dianzani MU, Poli G, Slater TF (1982): Separation and characterization of the aldehydic products of lipid peroxidation stimulated by ADP-Fe2+ in rat liver microsomes. Biochem. J. 208, 129-40

17. Filler R (1993): Methods for evaluation of rat epididymal sperm morphology. Methods in Toxicology 3, 334-343

18. Grabke A, Fernández-Ortuño D, Amiri A, Li X, Peres NA, Smith P, Schnabel G (2014): Characterization of iprodione resistance in Botrytis cinerea from strawberry and blackberry. Phytopathology 104, 396402

19. Guido C, Santoro M, De Amicis F, Perrotta I, Panza S, Rago V, Cesario MG, Lanzino M, Aquila S (2014): Human sperm anatomy and endocrinology in varicocele: role of androgen receptor. Reproduction 147, 589-598

20. Hafez E (1970): Rabbits. Reproduction and breeding techniques for laboratory animals, 273-315

21. He X, Wu C, Cui Y, Zhu H, Gao Z, Li B, Hua J, Zhao B (2017): The aldehyde group of gossypol induces mitochondrial apoptosis via ROS-SIRT1-p53-PUMA pathway in male germline stem cell. Oncotarget 8,100128

22. Heikal TM, Mossa A, Ibrahim AW, Abdel-Hamid HF (2014): Oxidative damage and reproductive toxicity associated with cyromazine and chlorpyrifos in male rats: the protective effects of green tea extract. Res J Environ Toxicol 8, 53-67

23. Hull EM, Wood RI, McKenna KE (2006): Neurobiology of male sexual behavior. Knobil and Neill's physiology of reproduction 3, 1729-1824

24. Hussein RM, Mohamed WR, Omar HA (2018): A neuroprotective role of kaempferol against chlorpyrifos-induced oxidative stress and memory deficits in rats via GSK3 $\beta$-Nrf2 signaling pathway. Pestic. Biochem. Physiol. 152, 29-37

25. Ibrahim MA, Abd-El-Rahman HMA, M RZ, Abeer EE-M (2016): Studies on Some Biochemical, Hormonal, Histopathological and Seminal Characters in Relation to Rutting and Non-Rutting Season in Camels. Alexandria Journal of Veterinary Sciences 49, 189-202

26. Jana K, Jana S, Samanta PK (2006): Effects of chronic exposure to sodium arsenite on hypothalamo-pituitary-testicular activities in adult rats: possible an estrogenic mode of action. Reproductive Biology and Endocrinology 4, 9

27. Justulin LA, Jr., Ureshino RP, Zanoni M, Felisbino SL (2006): Differential proliferative response of the ventral prostate and seminal vesicle to testosterone replacement. Cell Biol. Int. 30, 354-64

28. Kolthur-Seetharam U, Teerds K, de Rooij DG, Wendling O, McBurney M, Sassone-Corsi P, Davidson I (2009): The histone deacetylase SIRT1 controls male fertility in mice through regulation of hypothalamic-pituitary gonadotropin signaling. Biology of reproduction 80, 384-391

29. Koracevic D, Koracevic G, Djordjevic V, Andrejevic S, Cosic V (2001): Method for the measurement of antioxidant activity in human fluids. J. Clin. Pathol. 54, 356-61

30. Kumar A, Margekar SL, Margekar P, Margekar V (2018): Recent advances in management of organophosphate \& carbamate poisoning. Indian Journal of Medical Specialities 9, 154-159 
31. Laporte B, Gay-Quéheillard J, Bach V, Villégier A-S (2018): Developmental neurotoxicity in the progeny after maternal gavage with chlorpyrifos. Food Chem. Toxicol. 113, 66-72

32. Lehrer RI, Lu W (2012): a-Defensins in human innate immunity. Immunol. Rev. 245, 84-112

33. Li J, Liu X, Ren C, Li J, Sheng F, Hu Z (2009): In vitro study on the interaction between thiophanate methyl and human serum albumin. Journal of Photochemistry and Photobiology B: Biology 94, 158163

34. Li J, Ren F, Li Y, Luo J, Pang G (2019): Chlorpyrifos induces metabolic disruption by altering levels of reproductive hormones. J. Agric. Food Chem. 67, 10553-10562

35. Li R, He L, Wei W, Hao L, Ji X, Zhou Y, Wang Q (2015): Chlorpyrifos residue levels on field crops (rice, maize and soybean) in China and their dietary risks to consumers. Food Control 51, 212-217

36. Lin CH, Li NT, Cheng HS, Yen ML (2018): Oxidative stress induces imbalance of adipogenic/osteoblastic lineage commitment in mesenchymal stem cells through decreasing SIRT1 functions. J. Cell. Mol. Med. 22, 786-796

37. Lin S-Y, Elledge SJ (2003): Multiple tumor suppressor pathways negatively regulate telomerase. Cell $113,881-889$

38. Livak KJ, Schmittgen TD (2001): Analysis of relative gene expression data using real-time quantitative PCR and the 2(-Delta Delta C(T)) Method. Methods (San Diego, Calif.) 25, 402-8

39. Ma M, Chen C, Yang G, Wang Y, Wang T, Li Y, Qian Y (2019): Combined anti-androgenic effects of mixtures of agricultural pesticides using in vitro and in silico methods. Ecotoxicol. Environ. Saf. 186, 109652

40. Mehrpour O, Karrari P, Zamani N, Tsatsakis AM, Abdollahi M (2014): Occupational exposure to pesticides and consequences on male semen and fertility: a review. Toxicol. Lett. 230, 146-156

41. Morgan AM, El-Aty AA (2008): Reproductive toxicity evaluation of Pestban insecticide exposure in male and female rats. Toxicological Research 24, 137-150

42. Mossa A-TH, Swelam ES, Mohafrash SM (2015): Sub-chronic exposure to fipronil induced oxidative stress, biochemical and histopathological changes in the liver and kidney of male albino rats. Toxicology reports 2, 775-784

43. Nakayama A, Okawa H, Zheng M, Pu S, Watanabe G, Ohta R, Kawaguchi M (2018): Male Hatano lowavoidance rats show more active sexual behavior with lower plasma testosterone than highavoidance rats. J. Vet. Med. Sci., 17-0668

44. Pascual P, Martinez-Lara E, Barcena JA, Lopez-Barea J, Toribio F (1992): Direct assay of glutathione peroxidase activity using high-performance capillary electrophoresis. J. Chromatogr. 581, 49-56

45. Payne A (1996): Structure, function and regulation of steroidogenic enzymes in the Leydig cell. The Leydig Cell, 259-268

46. Peiris DC, Dhanushka T (2017): Low doses of chlorpyrifos interfere with spermatogenesis of rats through reduction of sex hormones. Environmental Science and Pollution Research 24, 20859-20867 
47. Perez-Fernandez C, Morales-Navas M, Aguilera-Sáez LM, Abreu AC, Guardia-Escote L, Fernández I, Garrido-Cárdenas JA, Colomina MT, Giménez E, Sánchez-Santed F (2020): Medium and long-term effects of low doses of Chlorpyrifos during the postnatal, preweaning developmental stage on sociability, dominance, gut microbiota and plasma metabolites. Environ. Res. 184, 109341

48. Pisani C, Voisin S, Arafah K, Durand P, Perrard M-H, Guichaoua M-R, Bulet P, Prat O (2016): Ex vivo assessment of testicular toxicity induced by carbendazim and iprodione, alone or in a mixture. ALTEX-Alternatives to animal experimentation 33, 393-413

49. Radice S, Marabini L, Gervasoni M, Ferraris M, Chiesara E (1998): Adaptation to oxidative stress: effects of vinclozolin and iprodione on the HepG2 cell line. Toxicology 129, 183-191

50. Radice S, Ferraris M, Marabini L, Grande S, Chiesara E (2001): Effect of iprodione, a dicarboximide fungicide, on primary cultured rainbow trout (Oncorhynchus mykiss) hepatocytes. Aquat. Toxicol. 54, 51-58

51. Rato L, Alves MG, Duarte AI, Santos MS, Moreira PI, Cavaco JE, Oliveira PF (2015): Testosterone deficiency induced by progressive stages of diabetes mellitus impairs glucose metabolism and favors glycogenesis in mature rat Sertoli cells. The international journal of biochemistry \& cell biology $66,1-10$

52. Rizzati V, Briand O, Guillou H, Gamet-Payrastre L (2016): Effects of pesticide mixtures in human and animal models: an update of the recent literature. Chem. Biol. Interact. 254, 231-246

53. Robbins A (1996): Androgens and male sexual behavior from mice to men. Trends in Endocrinology \& Metabolism 7, 345-350

54. Rone MB, Fan J, Papadopoulos V (2009): Cholesterol transport in steroid biosynthesis: role of protein-protein interactions and implications in disease states. Biochimica et Biophysica Acta (BBA)-Molecular and Cell Biology of Lipids 1791, 646-658

55. Röpke A, Tewes A-C, Gromoll J, Kliesch S, Wieacker P, Tüttelmann F (2013): Comprehensive sequence analysis of the NR5A1 gene encoding steroidogenic factor 1 in a large group of infertile males. Eur. J. Hum. Genet. 21, 1012

56. Sahin E, Colla S, Liesa M, Moslehi J, Müller FL, Guo M, Cooper M, Kotton D, Fabian AJ, Walkey C (2011): Telomere dysfunction induces metabolic and mitochondrial compromise. Nature 470, 359365

57. Sakr SA, Mahran HA, Nofal AE (2012): Effect of selenium on carbimazole-induced histopathological and histochemical alterations in prostate of albino rats. American Journal of Medicine and Medical Sciences 2, 5-11

58. Seed J, Chapin RE, Clegg ED, Dostal LA, Foote RH, Hurtt ME, Klinefelter GR, Makris SL, Perreault SD, Schrader S (1996): Methods for assessing sperm motility, morphology, and counts in the rat, rabbit, and dog: a consensus report. Reprod. Toxicol. 10, 237-244

59. Sharma A, Shukla A, Attri K, Kumar M, Kumar P, Suttee A, Singh G, Barnwal RP, Singla N (2020): Global trends in pesticides: A looming threat and viable alternatives. Ecotoxicol. Environ. Saf. 201, 110812 
60. Sharma P, Huq AU, Singh R (2014): Cypermethrin-induced reproductive toxicity in the rat is prevented by resveratrol. J. Hum. Reprod. Sci. 7, 99

61. Shittu M, Ayo J, Ambali S, Fatihu M, Onyeanusi B, Kawu M (2012): Chronic chlorpyrifos-induced oxidative changes in the testes and pituitary gland of Wistar rats: Ameliorative effects of vitamin $\mathrm{C}$. Pestic. Biochem. Physiol. 102, 79-85

62. Suvarna KS, Layton C, Bancroft JD (2018): Bancroft's theory and practice of histological techniques E-Book. Elsevier Health Sciences

63. Vachharajani VT, Liu T, Wang X, Hoth JJ, Yoza BK, McCall CE (2016): Sirtuins link inflammation and metabolism. Journal of immunology research 2016

64. Visalakshmi V, Raju M, Rao AU, Kumar KM, Satyanarayana NH (2016): Compatibility and efficacy of insecticide and fungicide combinations on major pests and sheath blight of paddy. Nature Environment and Pollution Technology 15, 233

65. Wang X-I, Wu L-y, Zhao L, Sun L-n, Liu H-y, Liu G, Guan G-j (2016): SIRT1 activator ameliorates the renal tubular injury induced by hyperglycemia in vivo and in vitro via inhibiting apoptosis. Biomed. Pharmacother. 83, 41-50

66. Watts M (2012): Chlorpyrifos as a possible global POP. Pesticide Action Network North America, Oakland, CA. www. pan-europe. info/News/PR/121009_Chlorpyrifos_as_POP_final. pdf

67. Weikert S, Christoph F, Schulze W, Krause H, Kempkensteffen C, Schostak M, Miller K, Schrader M (2006): Testicular expression of survivin and human telomerase reverse transcriptase (hTERT) associated with spermatogenic function in infertile patients. Asian journal of andrology 8, 95-100

68. Xu L, Luo G, Sun Y, Huang S, Xu D, Xu G, Han Z, Gu Z, Zhang Y (2020): Multiple down-regulated cytochrome $\mathrm{P} 450$ monooxygenase genes contributed to synergistic interaction between chlorpyrifos and imidacloprid against Nilaparvata lugens. J. Asia-Pacif. Entomol. 23, 44-50

69. Xu M-Y, Wang P, Sun Y-J, Wu Y-J (2017): Metabolomic analysis for combined hepatotoxicity of chlorpyrifos and cadmium in rats. Toxicology 384, 50-58

70. Xu M-Y, Wang P, Sun Y-J, Wu Y-J (2018): Disruption of Kidney Metabolism in Rats after Subchronic Combined Exposure to Low-Dose Cadmium and Chlorpyrifos. Chem. Res. Toxicol. 32, 122-129

71. Yang YY, Lai CT (2019): Synergistic effect and field control efficacy of the binary mixture of permethrin and chlorpyrifos to brown planthopper (Nilaparvata lugens). J. Asia-Pacif. Entomol. 22, 67-76

72. Zhang X, Cui W, Wang K, Chen R, Chen M, Lan K, Wei Y, Pan C, Lan X (2020): Chlorpyrifos inhibits sperm maturation and induces a decrease in mouse male fertility. Environ. Res. 188, 109785

73. Zidan N (2009): Evaluation of the reproductive toxicity of chlorpyrifos methyl, diazinon and profenofos pesticides in male rats. Int J Pharmacol 5, 51-57

74. Zimmer KE, Montaño M, Olsaker I, Dahl E, Berg V, Karlsson C, Murk AJ, Skaare JU, Ropstad E, Verhaegen S (2011): In vitro steroidogenic effects of mixtures of persistent organic pollutants (POPs) extracted from burbot (Lota lota) caught in two Norwegian lakes. Sci. Total Environ. 409, 2040-2048 


\section{Figures}

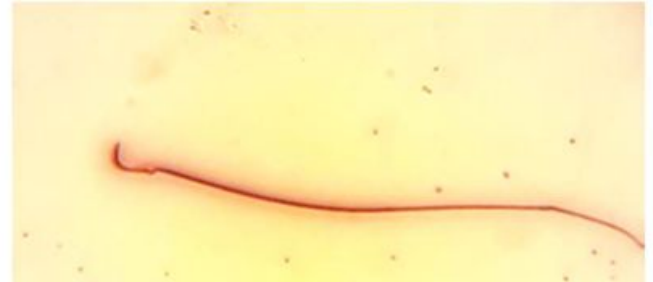

\section{A}
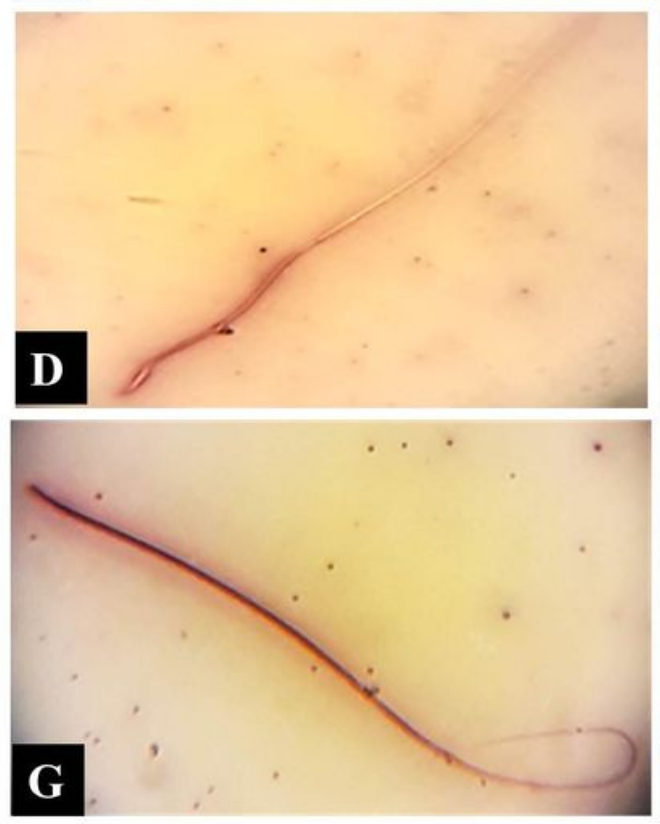

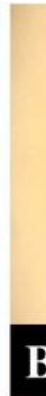

\section{B}
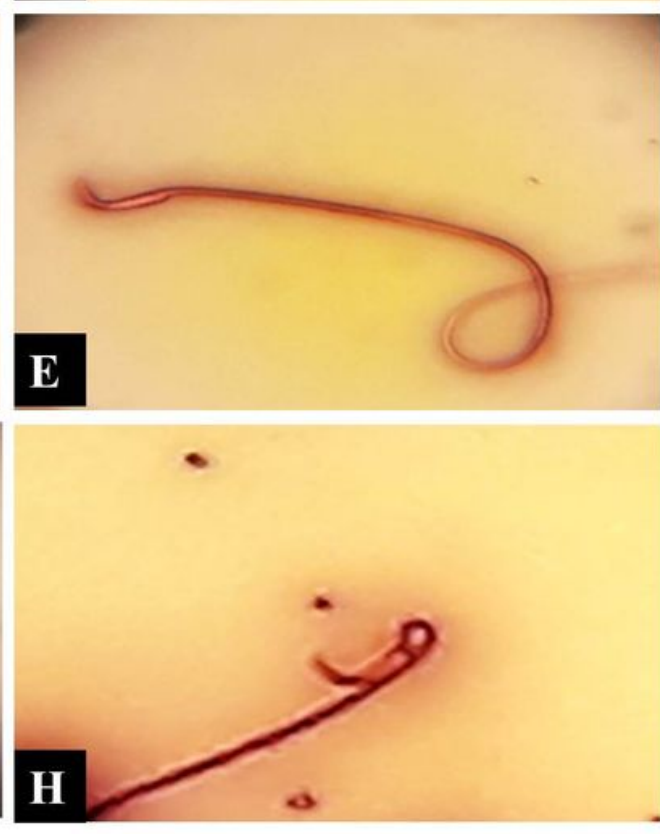
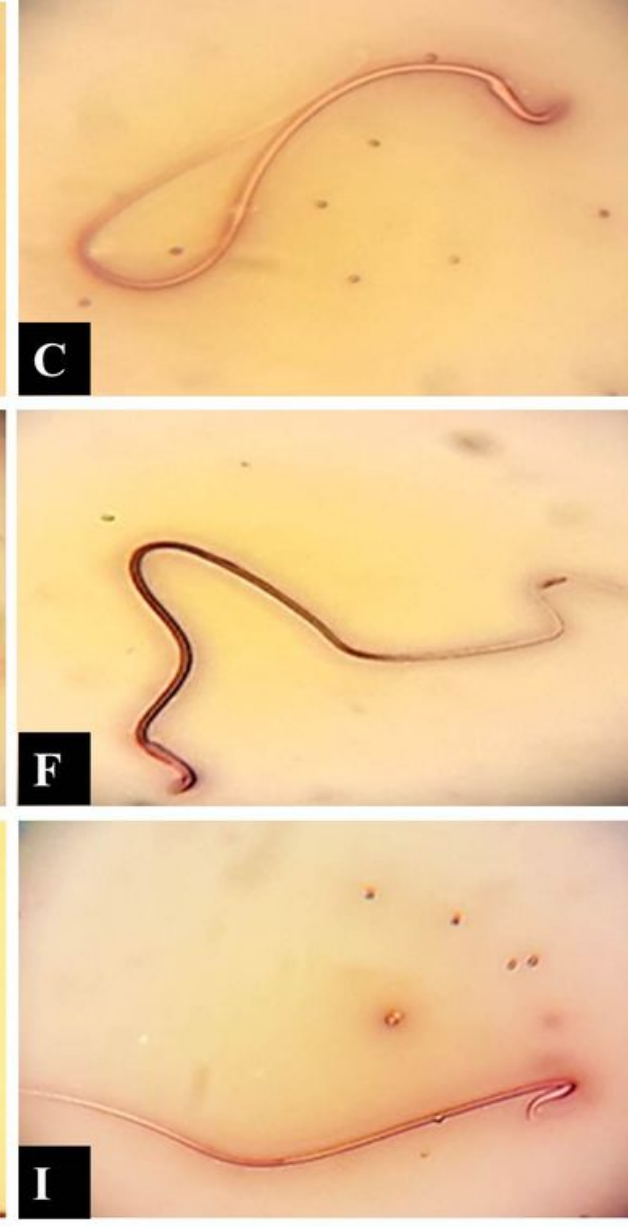

\section{Figure 1}

Photomicrographs of eosin-nigrosin-stained semen smears of IPR and/or CPF exposed rats for 65 days showing different forms of sperm abnormalities, including detached tail (B), looped tail (C), abnormal hookless head $(D)$, coiled tail $(E)$, curved tail $(F)$, detached head $(G)$, bent neck $(H)$, bent neck with a hookless head (I). Photomicrographs of semen smear of the control rats showing sperms with normal morphology (A) (100x). 


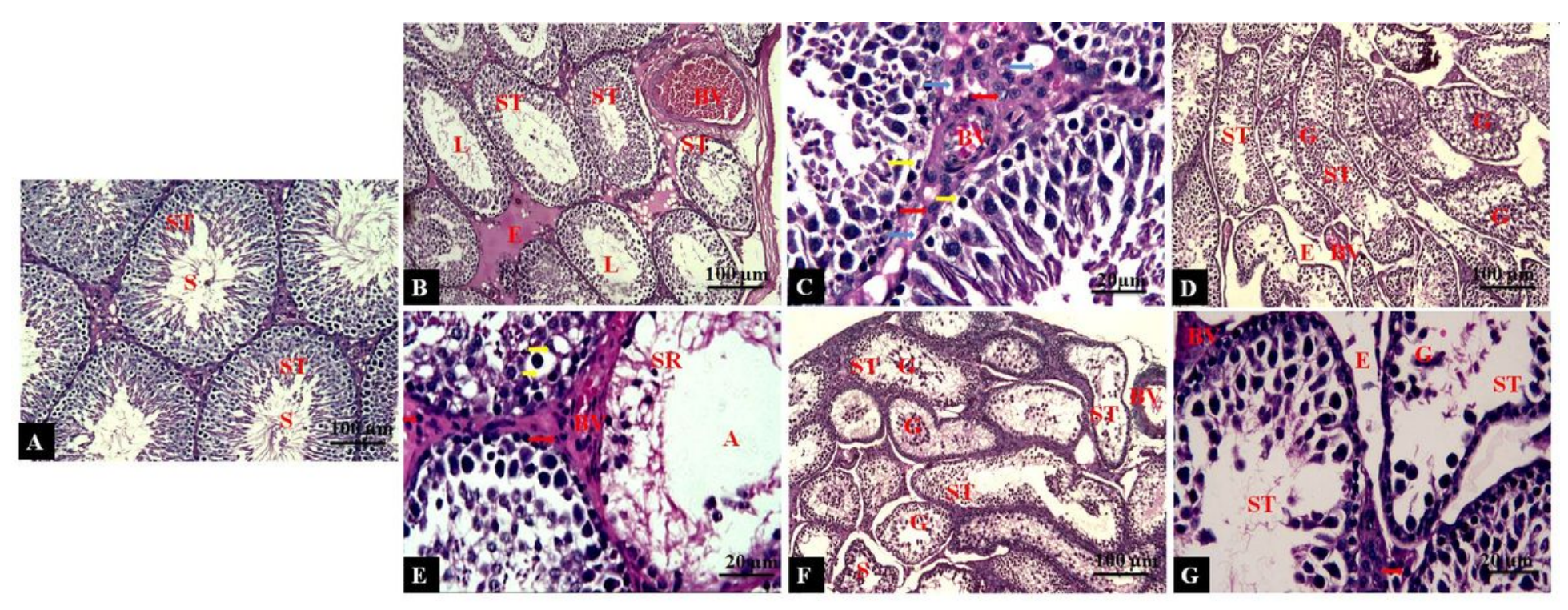

Figure 2

A: Testis of the control group showing closely packed seminiferous tubules with full spermatogenesis and containing sperms in their lumens with narrow well-developed interstitial spaces. B: Testis of IPR group showing a decrease in the spermatogenic cells number of with vacuoles formations in seminiferous tubules, cellular debris in the lumen, lumen devoid of sperms, Leydig cells vacuolations, interstitial edema and dilated hypertrophied . C: Testis of IPR group showing seminiferous tubules with cytoplasmic vacuolation and pyknotic nuclei of spermatogonia, sloughing germinal epithelium, disturbed spermatogenesis, interstitial vacuolations, and inflammatory cells, and congested blood vessels. D: Testis of CPF group showing irregular seminiferous tubules with interrupted spermatogenesis sloughed of the germinal epithelium into the lumen, absence of sperms in the tubular lumen, congested blood vessels and interstitial edema. E: Testis of CPF group showing seminiferous tubules with cytoplasmic vacuolations and pyknotic nuclei, desquamated germinal epithelium, debris of spermatids, tubular atrophy with a complete absence of spermatogonial cells, degenerated Sertoli cells with pyknotic nuclei, congested blood vessels, and interstitial inflammatory cells. F: Testis of IPR+CPF group showing severely damaged irregular seminiferous tubules along with atrophy, desquamated germinal epithelium, and loss of spermatozoa in the lumen and congestion of blood vessels. G: Testis of IPR+CPF group showing damaged atrophied seminiferous tubules with pyknotic nuclei and complete absence of spermatogonial cells, sloughing germinal epithelium with inflammatory cells, and congested blood vessels.

(Abbreviations: Seminiferous tubules: ST; Germinal epithelium: G; Spermatogonial cells: A; Cytoplasmic vacuolations and pyknotic nuclei: yellow arrow; Sertoli cell: SR; Sperms: S; Lumen: L; Interstitial spaces: l; Leydig cells: blue arrow; Interstitial vacuolations: blue arrow; Interstitial inflammatory cells: red arrow; Edema: E; Blood vessel: BV). 


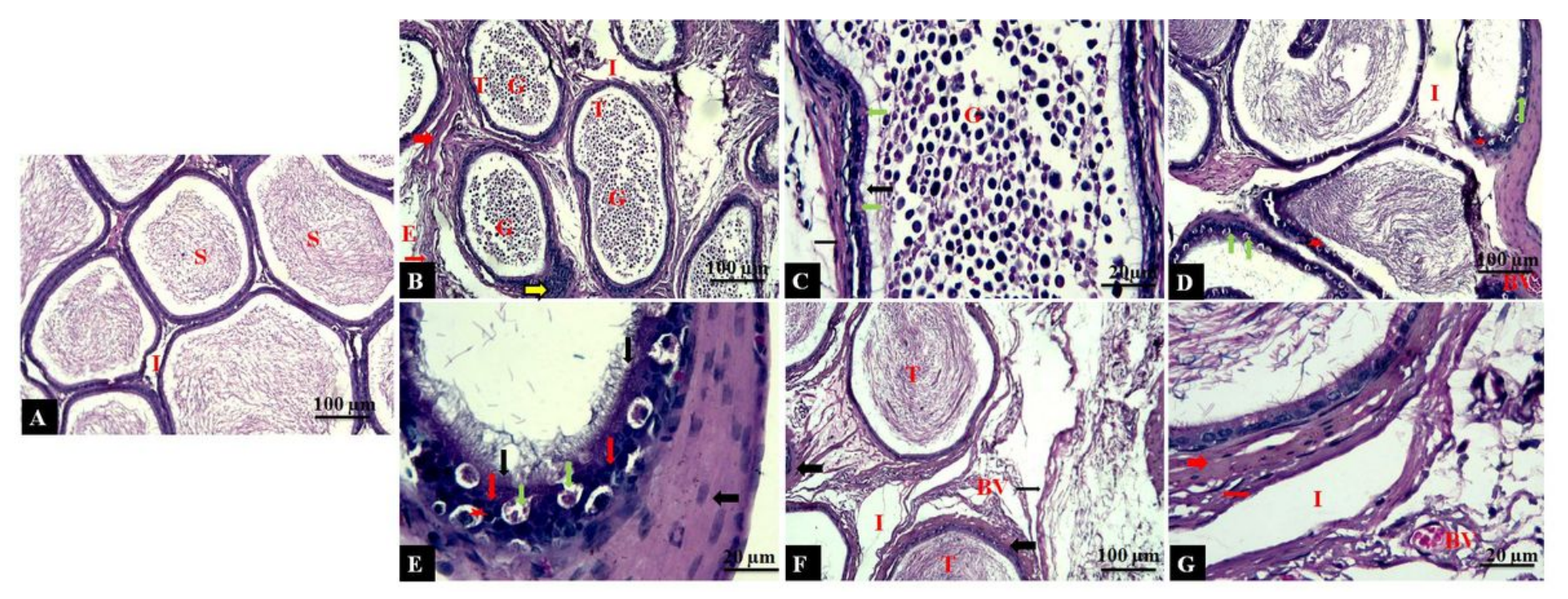

Figure 3

A: Epididymis of the control group showing regular circular tubules containing many sperms in their lumen and separated by interstitial tissues. B: Epididymis of IPR-treated rats showing irregular destructed tubules containing numerous exfoliated germ cells, abnormal round germ cells, and cell debris in their lumens, edematous interstitial spaces, thickened smooth muscle layer, and increased connective tissue between the tubules and monocellular inflammatory cells. C: Epididymis of IPR-treated rats showing irregular tubule lined with vacuolated principal cells, hypertrophy of the clear cells, filled with numerous abnormal round germ cells and cell debris, and increased connective tissue around tubule. D: Epididymis of CPF-treated rat showing irregularity of the tubules, appearance of halo cells, hypertrophy of the clear cells, widening of the interstitial spaces containing thickened smooth muscle layer, increased connective tissue, and congested blood vessels. E: Epididymis of CPF-treated rats showing tubule lined with vacuolated principal cells with destructed stereocilia, hypertrophy of clear cells with pale cytoplasm, small rounded halo cells in between inflammatory cells, thickened smooth muscle layer, and absence of spermatozoa. F: Epididymis of IPR and CPF-treated rats showing irregular tubules containing sperms and cell debris in their lumens, wide interstitial spaces with edema, thickened smooth muscle layer, edematous connective tissue, and congested blood vessels. G: Epididymis of IPR and CPF-treated rats showing tubule surround by thickened smooth muscle layer, connective tissue, wide interstitial spaces with edema, congested blood vessels, inflammatory cells as well as sperms and cell debris in their lumens. (Abbreviations: Tubules: T; Germ cell: G; Principal cell: arrow; Clear cell: green arrow; Halo cell: star; Principal cell with stereocilia: arrow; Sperms: S; Interstitial tissues: I; Monocellular inflammatory cells: yellow arrow; Smooth muscle layer: thick arrow; Connective tissue: thin arrow; Blood vessel: BV). 


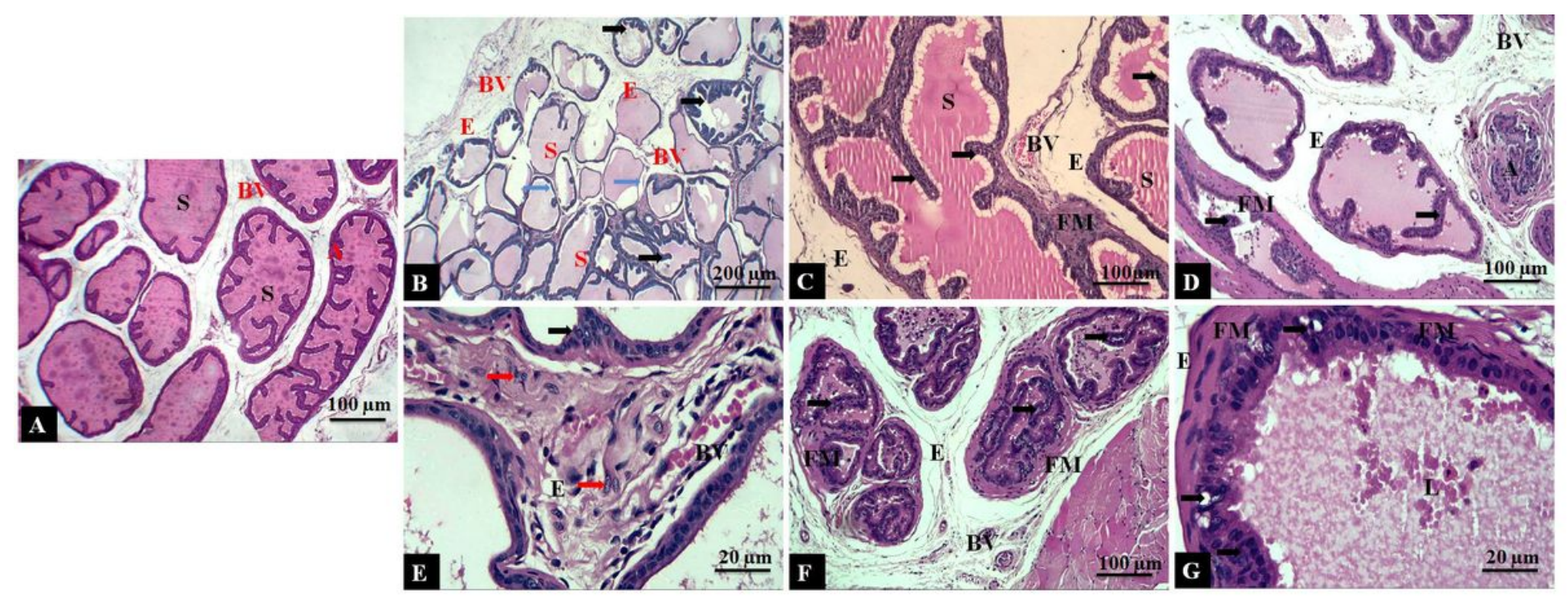

Figure 4

A: Prostate gland of the control group showing normal acini with pink prostatic secretions in the lumen.

B: Prostate gland of IPR-treated rat showing mild epithelial hyperplasia in some acini with papillary formations, other alveoli were enlarged with flattened epithelial lining, destructed acini, pink secretion, interstitial and subcapsular edema as well as congestion of intertubular and prostatic capsule blood vessels. C: Prostate gland of IPR-treated rat showing epithelial hyperplasia in acini with papillary formation, secretion, the fibro-muscular layer's thickness, interstitial and subcapsular edema and congestion of blood vessels. D: Prostate gland of CPF-treated rat showing epithelial hyperplasia and papillary projections, destructed acini, prominent thickened fibro-muscular layer, interstitial edema, congested intertubular blood vessels. E: Prostate gland of CPF-treated rat showing epithelial hyperplasia, interstitial edema, congestion of intertubular blood vessels and vasculitis as well as peri-acinar inflammatory cells infiltration within proliferated interstitial tissue. F: Prostate gland of IPR and CPFtreated rat showing marked epithelial hyperplasia and papillary projections, acinar shrinkage with a narrow lumen that contained cellular debris, thickened fibro-muscular layer, interstitial edema, congested and vasculitis of intertubular blood vessels. G: Prostate gland of IPR and CPF-treated rat showing epithelial hyperplasia and vacuolations in acini, lumen contains secretion, cellular debris, and interstitial edema. (Abbreviations: Acini: A; Hyperplasia in some acini with papillary formations: arrow; Epithelial lining: blue arrow; Prostatic secretions: S; Lumen: L; Fibro-muscular layer: FM; Blood vessel: BV; Edema: E; Inflammatory cells infiltration: red arrow). 


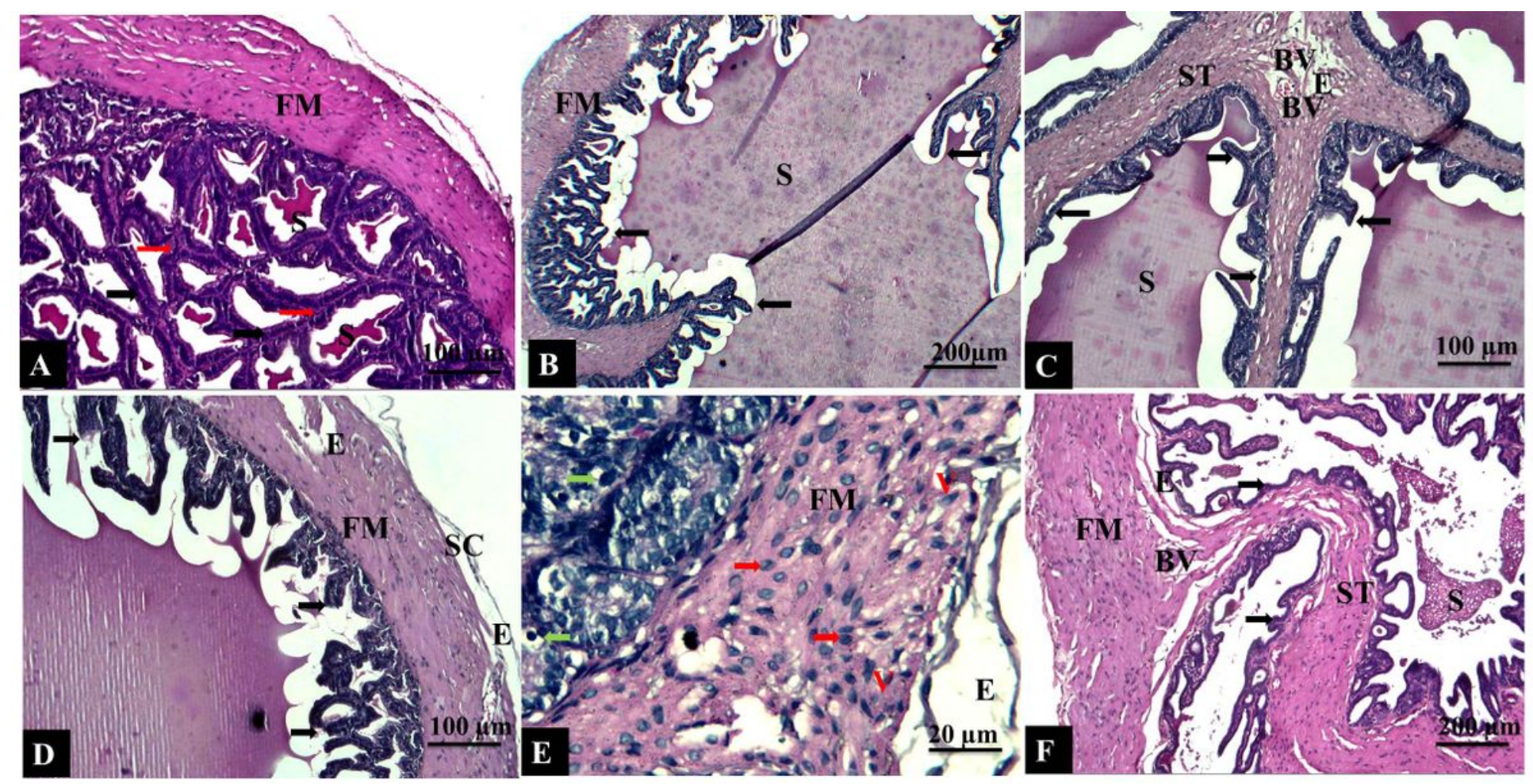

Figure 5

A: Seminal vesicle of the control group showing normal glandular structure with branched epithelial folds containing smooth muscle tissue in between, normal secretory accumulation of pink secretions and fibromuscular layer. B: Seminal vesicle of IPR group showing hyperplastic epithelial folds with papillary formations toward the lumen, secretion in the lumen and thickened fibro-muscular layer. C: Seminal vesicle of IPR group showing hyperplasia with papillary formations, secretion, increased thickness of supporting stroma of the folds with edema, and congested blood vessels. D: Seminal vesicle of CPF group showing hyperplasia with destructed epithelial folds, secretion inside the acinar lumen, edema in the fibro-muscular layer, and subcapsular layer. E: Seminal vesicle of CPF group showing glandular hyperplasia with vacuolated epithelium, vacuolations, and mononuclear inflammatory cells in the thickened fibro-muscular layer and subcapsular edema. F: Seminal vesicle of IPR and CPF-treated rat showing glandular atrophy with decreasing in height and number of epithelial folds, increasing of stromal and fibro-muscular layer thickness, reduction of vesicular fluid in the lumen, congestion and vasculitis of blood vessels, and edema. (Abbreviations: Epithelial folds: black arrow; Secretions: S; Smooth muscle tissue: red arrow; Fibro-muscular layer: FM; Supporting stroma: ST; Edema: E; Blood vessels: BV; Vacuolations: V; Mononuclear inflammatory cells: red arrow; Subcapsular layer: SC). 


\section{A}

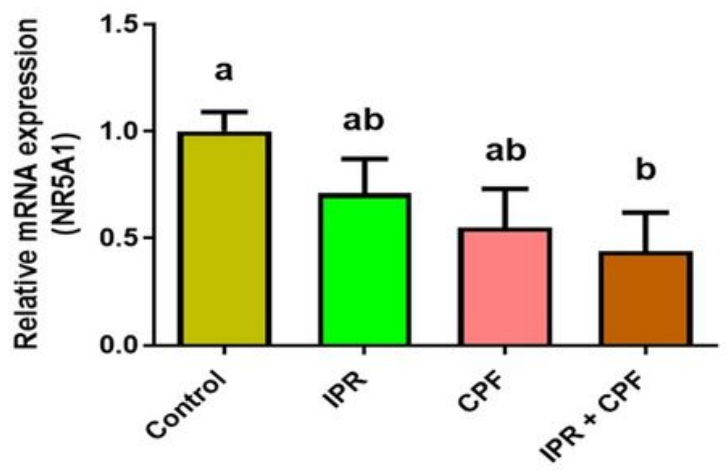

B

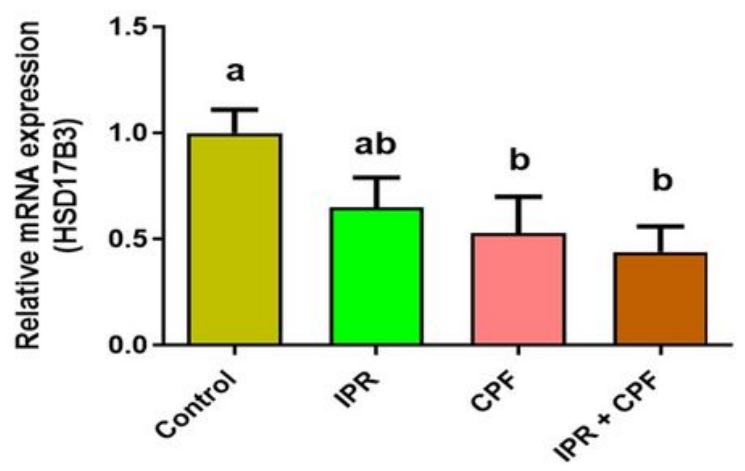

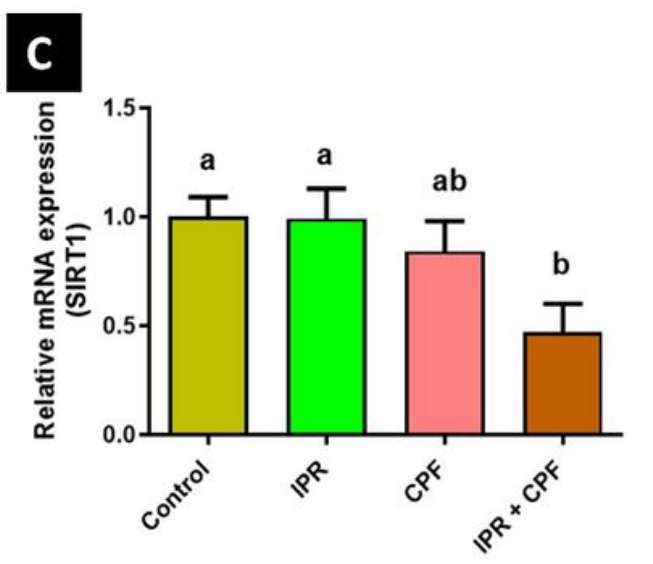
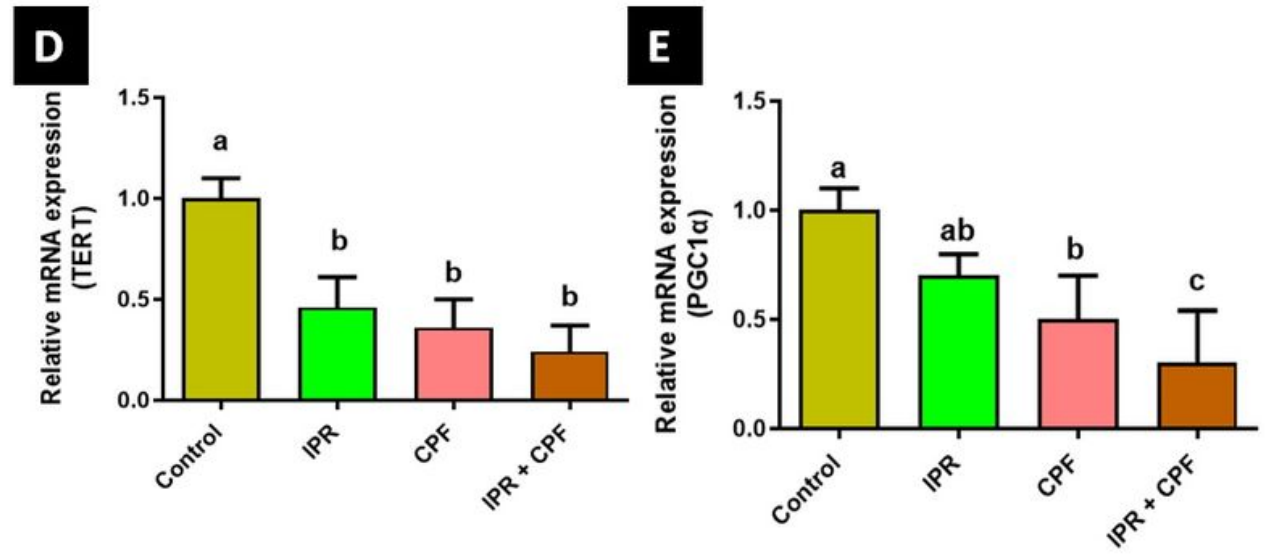

Figure 6

Effect of iprodione (IPR) and/or chlorpyrifos (CPF) administration on mRNA expression of NR5A1, HSD17B3, SIRT1, TERT and PGC1 $a$ in testicular tissue of adult rats. Different letters $(a, b$, and $c)$ by bars indicate significant differences $(p<0.05)$. Values are mean $\pm S E(n=10 /$ group $)$. 